\title{
Distribusi Kandungan Karbon Total Sedimen Dasar Di Perairan Muara Sungai Kaliboyo, Batang
}

\author{
Asri Wahyuningsih ${ }^{1 *}$, Warsito Atmodjo ${ }^{2}$, Sri Yulina Wulandari ${ }^{2}$, Lilik Maslukah $^{2}$ dan Muslim $^{2}$ \\ ${ }^{1}$ Program Sarjana Departemen Oseanografi, Fakultas Perikanan dan Ilmu Kelautan \\ ${ }^{2}$ Departemen Oseanografi, Fakultas Perikanan dan Ilmu Kelautan, Universitas Diponegoro \\ Jl. Prof Soedarto, SH. Kampus UNDIP Tembalang Semarang 50275 \\ Email: *asriwahyuningsih760@gmail.com.com
}

\begin{abstract}
Abstrak
Perairan muara Sungai Kaliboyo terletak di sebelah timur Kabupaten Batang, tepatnya di Desa Roban. Daerah sekitar perairan muara Sungai Kaliboyo digunakan berbagai kegiatan masyarakat seperti pemukiman, tempat pelelangan ikan, pertambakan dan tempat keluar masuk perahu nelayan. Tingginya aktivitas di sekitar perairan menjadi jalur masukan limbah domestik ke perairan, yang mengandung bahan organik. Penelitian ini bertujuan untuk mengetahui kandungan karbon total dalam sedimen dan mengetahui distribusi karbon total dalam sedimen. Pengambilan data dilakukan pada bulan September 2018. Metode yang digunakan dalam penelitian ini yaitu metode analisa deskriptif eksploratif. Metode analisis pengukuran karbon total dalam sedimen menggunakan metode Loss on Ignation (LOI\%), sedangkan metode ukuran butir menggunakan metode pengayakan dan pemipetan. Hasil penelitian ini adalah kandungan karbon total pada fraksi pasir berkisar antara 5,89\% - 18,53\%, sedangkan kandungan karbon total pada fraksi lanau lempungan berkisar antara 15,74 \% - 53,33\%. Kandungan karbon total lebih tinggi pada fraksi lanau lempungan dibandingkan dengan fraksi pasir. Distribusi kandungan karbon total lebih dipengaruhi jauh dekatnya dari sumber masukan bahan organik, lebih tinggi didaerah muara dan semakin menurun ke arah lepas pantai.
\end{abstract}

Kata kunci: Distribusi, Karbon Total, Perairan Kaliboyo, Sedimen

\begin{abstract}
Abstrack
Kaliboyo waters is located in the eastern part of the Batang precisely Roban village. The area around the waters of the Kaliboyo waters is used by various community activities such as settlements, fish auction, aquaculture and fishing boats exit. The high activity around the waters becomes the input path for domestic waste into the waters, which contains organic matter. This study was aimed to determine the total carbon content in sediments and determine the distribution of total carbon in sediments. The data were taken on September. The method used in this research is explorative descriptive analysis method. Measuring total carbon in the sediment used loss on ignition (LOI\%) method, while sediment particle size analysis used dry sieving and wet sieving method. The result showed concentration of total carbon in sand ranged between 5,89\%-18,53\%, while concentration of total carbon in clay silt ranged between 15,74\%-53,33\%. The total carbon content was higher in the clay silt fraction compared to the sand fraction. The distribution of total carbon content was influenced more closely by the source of input of matter, higher in the estuary area and lower towards offshore.
\end{abstract}

Keywords: Distribution, Kaliboyo-Waters, Total Carbon, Sediment

\section{PENDAHULUAN}

Perairan muara Sungai Kaliboyo terletak di sebelah timur Kabupaten Batang, tepatnya di Desa Roban. Kawasan perairan muara Sungai Kaliboyo merupakan titik akhir Daerah Aliran Sungai. Daerah sekitar perairan muara Sungai Kaliboyo digunakan berbagai kegiatan masyarakat seperti pemukiman, tempat pelelangan ikan, pertambakan dan tempat keluar masuk perahu nelayan. Tingginya aktivitas masyarakat menghasilkan limbah domestik, baik itu limbah organik maupun limbah anorganik yang dibuang melalui saluran air yang dialirkan oleh aliran sungai menuju ke muara.

Bahan organik adalah kumpulan beragam senyawa-senyawa organik kompleks yang sedang atau telah mengalami proses dekomposisi, baik berupa humus hasil humifiksasi maupun senyawa-senyawa anorganik hasil mineralisasi dan termasuk juga mikroba heterotrofik dan ototrofik yang terlibat (Nurfakih dan Suryono, 2013). Bahan organik tersusun oleh unsur-unsur C, H, O, dan beberapa 
mengandung N, S, P dan Fe. Karbon yang merupakan penyusun utama bahan organik merupakan elemen atau unsur yang melimpah pada semua makhluk hidup (Hutasoit et al., 2014).

Bahan organik pada kolom perairan yang terbawa oleh aliran sungai akan mengalami proses dekomposisi oleh organisme pengurai. Bahan organik di perairan akan dirombak untuk menjadi bahan anorganik sebagai nutrien penting di perairan. Nutrien tersebut akan dipergunakan dalam proses produksi oleh produsen perairan dan sangat menentukan produktivitas primer di perairan (Riniatsih, 2015). Kemudian terjadi proses fisis (terbawa oleh aliran sungai) dan proses kimiawi (pertukaran ion). Proses fisis dan kimiawi inilah yang akan mengalami adsobsi dengan padatan suspensi. Suspensi tersebut akan turun dan mengendap di sedimen dasar perairan.

Bahan organik yang ada di dasar sedimen juga dapat terlepas kembali ke perairan tergantung dari beberapa faktor seperti ukuran butir sedimen serta kondisi perairan seperti arus, pasang surut, dissolve oxygen. Penentuan karbon organik total merupakan bagian penting dari karakterisasi lokasi atau penilaian ekologis karena dengan ada atau tidaknya dapat sangat mempengaruhi bahan kimia bereaksi di sedimen (Deming dan Yager, 1992). Bahan organik lebih mudah terikat dengan sedimen dengan butir halus yang menghasilkan karbon organik total lebih melimpah (Meng et al., 2014).

Penelitian ini bertujuan untuk mengetahui kandungan karbon organik total dan distribusi karbon organik total dalam sedimen perairan muara Sungai Kaliboyo.

\section{Kondisi Daerah Penelitian}

Secara geografis perairan muara Sungai Kaliboyo, Batang terletak pada posisi 6054'6.46" 6054'35.63" Lintang Selatan dan 109050'10.55" - 109050'49.05” Bujur Timur. Daerah perairan muara Sungai Kaliboyo ini memiliki kedalaman air berkisar antara 0,15 meter sampai 2 meter dan memiliki dasar yang landai.

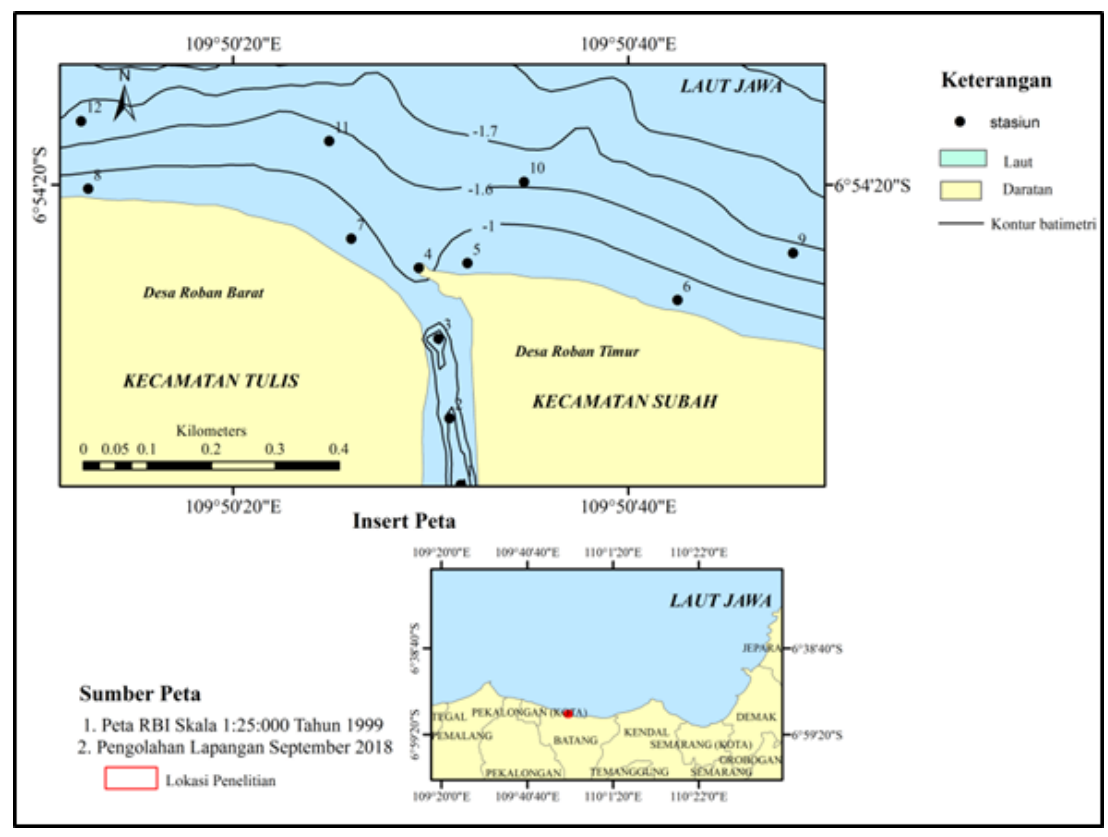

Gambar 1. Peta Lokasi Penelitian

\section{MATERI DAN METODE}

Materi yang digunakan dalam penelitian ini adalah sedimen yang diambil di Perairan muara Sungai Kaliboyo, diukur beberapa parameternya meliputi kandungan Karbon Organik Total, jenis ukuran butir sedimen dan $\mathrm{pH}$ sedimen. Selain parameter tersebut, dalam penelitian ini juga dilakukan pengambilan data debit sungai, bathimetri, pasang surut yang digunakan sebagai data pendukung.

Metode yang digunakan dalam penelitian ini adalah metode deskriptif eksploratif. Menutur Subandi (2011), untuk menggambarkan keadaan sesuatu fenomena. Penelitian ini tidak dimaksudkan 
untuk menguji hipotesis tertentu tapi hanya menggambarkan apa adanya sesuatu variable, gejala atau keadaan.

Metode yang digunakan dalam penentuan lokasi stasiun penelitian ini yaitu dengan menggunakan metode stratified purposive sampling (Sugiyono, 2014), yaitu metode dengan mempertimbangkan tujuan atau maksud dari penelitian. Jumlah titik pengambilan dilakukan sebanyak 12 stasiun menggunakan GPS (Global Position System). Penetapan 12 stasiun ini, terbagi atas 3 stasiun di muara sungai dengan mempertimbangkan masih ada pengaruh dari laut dan kondisi lingkungan perairan (sekitar kanan dan kiri muara sungai banyak timbunan sampah), 5 stasiun di dekat pinggir pantai dengan mempertimbangkan pengaruh laut dan pengaruh dari muara sungai, 4 stasiun di lepas pantai dengan mempertimbangkan hanya pengaruh dari laut.

\section{Metode Analisis Sampel}

Analisis debit muara sungai dengan mengukur kecepatan aliran dan luas penampang melintang. Rumus perhitungan debit sungai adalah (Sosrodarsono dan Takeda, 2003).

$$
\begin{gathered}
\mathrm{Qd}=\mathrm{Fd} \times \mathrm{Vd} \\
\mathrm{Fd}=2 \times \mathrm{b} \times(\mathrm{c}+2 \mathrm{~d}+\mathrm{e}) / 4
\end{gathered}
$$

Keterangan:

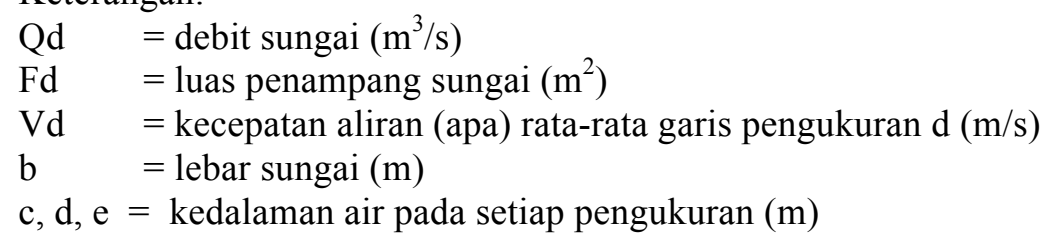

Analisa kandungan karbon Total menggunakan metode \%Loi (loss on ignition) mengacu pada (Meng et al., 2014). Hasil akhir konsentrasi dapat dihitung menggunakan rumus:

$$
\text { LOI }=\frac{(\text { Berat Sebelum Pengabuan }- \text { Berat Setelah Pengabuan })}{\text { Berat Sedimen Kering }} \times 100 \%
$$

Analisa jenis sedimen menggunakan metode pengayakan (Poerbandono dan Djunarsjah. 2005) dan pemipetan (Wibisono. 2005).

\section{HASIL DAN PEMBAHASAN}

\section{Debit Muara Sungai}

Pengukuran debit di muara Sungai Kaliboyo dilakukan secara insitu. Data hasil pengukuran dibagi menjadi 3 segmen, seperti pada tabel 1. Debit sungai yang kecil mengakibatkan pergerakan aliran air yang cukup lambat dan menyebabkan partikel-partikel halus mengendap seperti halnya stasiun 1 ,

\begin{tabular}{|c|c|c|c|c|c|c|c|c|c|}
\hline \multirow{2}{*}{ No } & \multirow{2}{*}{ Segmen } & \multirow{2}{*}{$\begin{array}{l}\text { Lebar } \\
\text { Sungai } \\
(\mathrm{m})\end{array}$} & \multirow{2}{*}{$\begin{array}{c}\text { Lebar } \\
\text { Penampang } \\
\text { (m) }\end{array}$} & \multicolumn{3}{|c|}{$\begin{array}{c}\text { Kedalaman } \\
(\mathrm{m})\end{array}$} & \multirow{2}{*}{$\begin{array}{c}\mathrm{Vd} \\
(\mathrm{m} / \mathrm{s})\end{array}$} & \multirow{2}{*}{$\begin{array}{l}\mathrm{Fd} \\
\mathrm{m}^{2}\end{array}$} & \multirow{2}{*}{$\begin{array}{c}\text { Qd } \\
\left(\mathrm{m}^{3} / \mathrm{s}\right)\end{array}$} \\
\hline & & & & $\mathrm{c}$ & d & e & & & \\
\hline 1 & Dekat Laut & 55,65 & 14 & 1,4 & 1,8 & 1,6 & 0 & 45,9113 & 0,0918 \\
\hline 2 & $\begin{array}{l}\text { Tengah } \\
\text { Muara }\end{array}$ & 56,2 & 14,05 & 1,2 & 1,4 & 1,1 & 0,17 & 35,8275 & 5,9832 \\
\hline 3 & $\begin{array}{l}\text { Badan } \\
\text { Sungai }\end{array}$ & 63,4 & 15,85 & 1,9 & 2 & 1,7 & 0,17 & 60,23 & 10,058 \\
\hline
\end{tabular}
stasiun 2, stasiun 3 dan stasiun 4 .

Tabel 1. Debit Muara Sungai Kaliboyo, Batang 
Data pasang surut BMKG Semarang bulan September 2018 yang dianalisis dengan menggunakan metode Admiralty diperoleh nilai konstanta harmonik pasang surut di perairan muara Sungai Kaliboyo yang dapat dilihat pada Tabel 2. Berdasarkan hasil nilai formzahl maka tipe pasang surut yaitu condong harian ganda. Nilai HHWL (Highest High Water Level) adalah $126 \mathrm{~cm}$. Nilai LLWL (Lowest Lower Water Level) adalah $13 \mathrm{~cm}$. Nilai MSL (Mean Sea Level) adalah $62 \mathrm{~cm}$. Nilai Fromzal sebesar 0,9. Grafik Pasang surut dapat dilihat pada Gambar 2.

Tabel 2. Komponen Pasang Surut Menggunakan Metode Admiralty

\begin{tabular}{ccc}
\hline Koefisien & Amplitudo $(\mathrm{cm})$ & Beda Fasa $\left(\mathrm{g}^{0}\right)$ \\
\hline $\mathrm{S}_{0}$ & 62 & 0 \\
$\mathrm{M}_{2}$ & 15 & 216 \\
$\mathrm{~S}_{2}$ & 10 & 292 \\
$\mathrm{~N}_{2}$ & 4 & 46 \\
$\mathrm{~K}_{1}$ & 19 & 56 \\
$\mathrm{O}_{1}$ & 4 & 115 \\
$\mathrm{M}_{4}$ & 1 & 77 \\
$\mathrm{MS}_{4}$ & 2 & 214 \\
$\mathrm{~K}_{2}$ & 3 & 292 \\
$\mathrm{P}_{1}$ & 6 & 56 \\
\hline
\end{tabular}

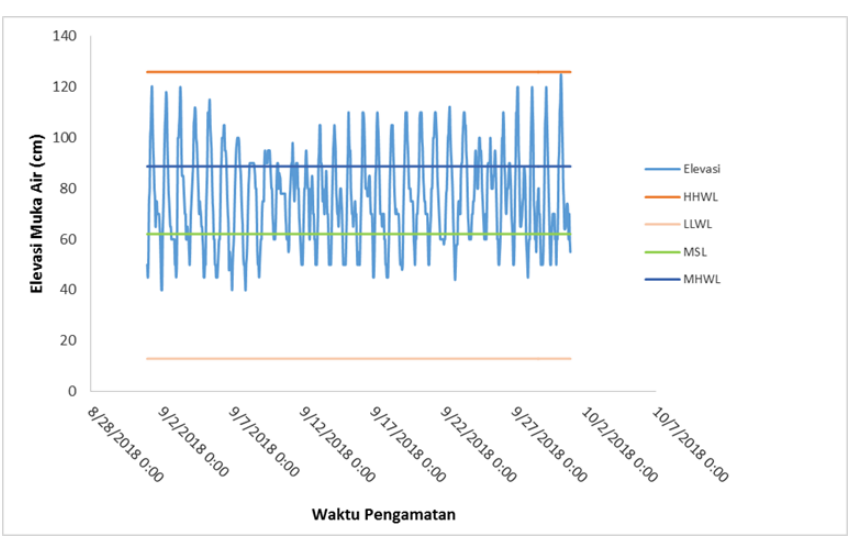

Gambar 2. Grafik Pasang Surut

\section{Karbon Organik Total}

Hasil perhitungan kandungan karbon organik total pada fraksi pasir memiliki rata- rata 5,89\%$18,53 \%$. kandungan karbon organik total pada fraksi lanau lempungan dipeoleh rata-rata antara $15,74 \%$ $53,33 \%$. Analisis pengukuran butir didapatkan jenis sedimen yang didominasi oleh jenis sedimen pasir. Nilai derajat keasaman pada sedimen berkisar antara 5,3-6,4. Hasil lebih jelasnya dapat dilihat pada Tabel 3.

Jika dilihat pada Gambar 3, nilai kandungan karbon organik total dalam sedimen semakin ke arah laut semakin turun nilainya. Turunnya nilai kandungan organik total diduga oleh faktor kurangnya suplai bahan organik dari daratan dan pergerakan arus pasang surut yang mempengaruhi pola distribusi dan pasokan material organik yang berasal dari sungai. Pada saat air surut, massa air sungai akan lebih dominan sehingga kandungan material organik dan unsur-unsur hara di muara sungai menjadi lebih tinggi begitu sebaliknya.

Pada penelitian ini didapatkan stasiun yang berfraksi pasir rata-rata memiliki konsentrasi karbon organik total yang lebih rendah dibandingkan dengan stasiun yang berfraksi lanau lempungan. Hal ini diperkuat dengan pendapat Arisa (2014), jumlah karbon organik yang sedikit dibandingkan jenis sedimen yang halus, karena sedimen pasir halus memiliki luas permukaan lebih kecil dari pada luas permukaan sedimen kasar, maka kemampuan untuk mengikat karbon organik lebih banyak. 
Tabel 3. Konsentrasi karbon organik total pada sedimen dasar di Perairan muara Sungai Kaliboyo Batang

\begin{tabular}{|c|c|c|c|c|c|c|}
\hline \multirow{2}{*}{ Stasiun } & \multirow{2}{*}{ Kedalaman } & \multirow{2}{*}{$\mathrm{d} 50$} & \multirow{2}{*}{$\begin{array}{c}\text { Jenis } \\
\text { Sedimen }\end{array}$} & \multicolumn{2}{|c|}{ Karbon Organik Total (\%) } & \multirow{2}{*}{$\begin{array}{c}\mathrm{pH} \\
\text { Sedimen }\end{array}$} \\
\hline & & & & Pasir & Lanau lempung & \\
\hline 1 & 2 & 0,1 & Pasir Halus & 12,80 & 15,75 & 6,2 \\
\hline 2 & 1,4 & 0,1 & Pasir Halus & 18,25 & 21,20 & 6,2 \\
\hline 3 & 1,8 & 0,21 & Pasir Halus & 18,53 & 21,53 & 5,3 \\
\hline 4 & 1 & 0,23 & Pasir Halus & 7,25 & 50,00 & 6,2 \\
\hline 5 & 0,35 & 0,35 & Pasir Sedang & 13,54 & 17,24 & 6,2 \\
\hline 6 & 0,2 & 0,41 & Pasir Sedang & 10,11 & 53,33 & 6,4 \\
\hline 7 & 0,2 & 0,37 & Pasir Sedang & 7,27 & 26,75 & 6,0 \\
\hline 8 & 0,15 & 0,28 & Pasir Sedang & 8,74 & 36,36 & 6,2 \\
\hline 9 & 1,5 & 0,21 & Pasir Halus & 7,80 & 36,42 & 6,3 \\
\hline 10 & 1,25 & 0,27 & Pasir Sedang & 6,35 & 39,42 & 5,9 \\
\hline 11 & 1,25 & 0,38 & Pasir Sedang & 8,24 & 28,67 & 6,2 \\
\hline 12 & 1,9 & 0,2 & Pasir Halus & 5,90 & 22,11 & 6,3 \\
\hline
\end{tabular}

Sedimen yang memiliki fraksi lanau lempungan akan lebih aktif dalam reaksi kimia dari pada sedimen fraksi pasir. Serta ditambah stasiun 8 nilai kandungan pada lanau lempungan lebih tinggi dari yang lain dan letak lokasinya berdekatan dengan vegetasi mangrove yang menghasilkan serasah daun mangrove yang mengalami proses dekomposisi, dan menjadi sumber dari bahan organik (Supriadi, 2001).

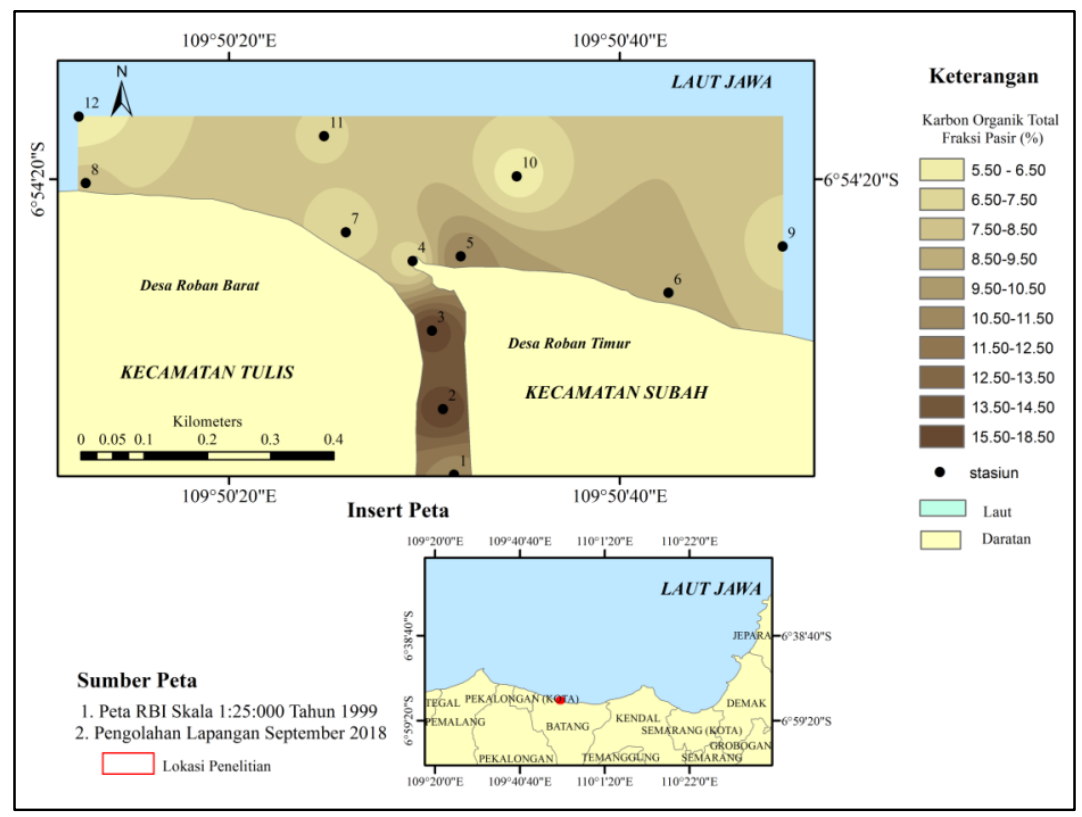

Gambar 3. Pola Sebaran Karbon Organik Total Fraksi Pasir

Hasil analisis pengukuran butir yang diwakili oleh 12 stasiun didapatkan jenis sedimen yang di dominasi oleh jenis sedimen pasir. Persebaran jenis sedimen ditampilkan pada Gambar 5. Data ukuran butir, menunjukan bahwa di perairan muara sungai Kaliboyo semakin ke utara jenis sedimennya berupa pasir sedang. Gambar 5, memperlihatkan bahwa diameter sedimen pada stasiun 5, stasiun 6, stasiun 7, 
stasiun 8 , stasiun 10 , stasiun 11 yaitu pasir sedang. Hal ini dipengaruhi oleh faktor pasang surut, dimana saat pasang volume air di daerah muara sungai bertambah dengan air yang berasal dari laut.

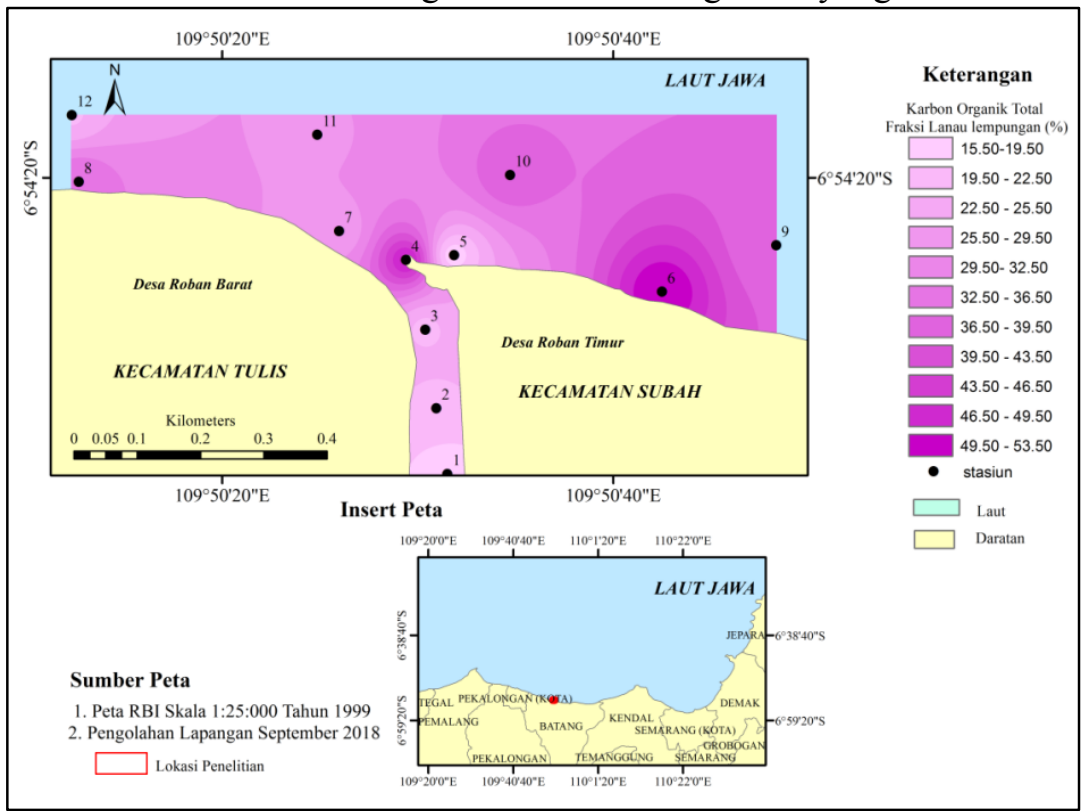

Gambar 4. Pola Peta Sebaran Karbon Organik Total Fraksi Lanau lempungan

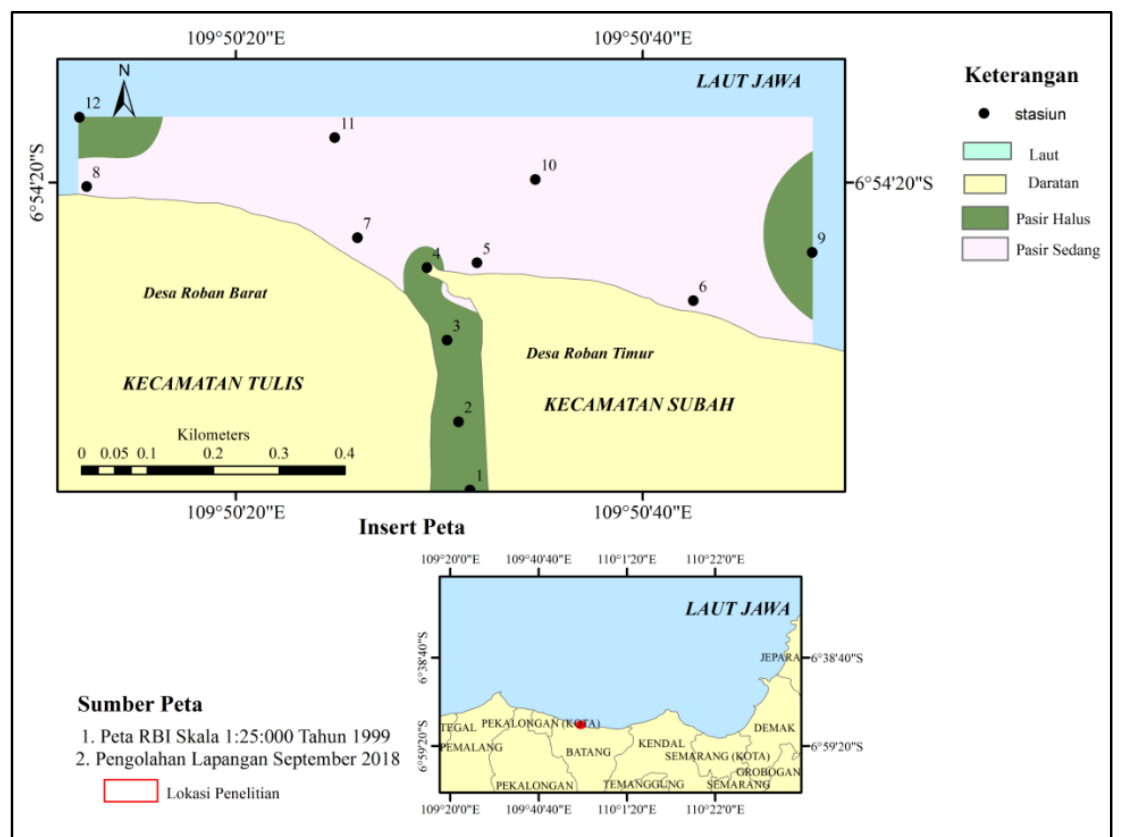

Gambar 5. Peta Sebaran Sedimen Dasar

\section{KESIMPULAN}

Kandungan karbon organik total pada fraksi pasir berkisar antara 5,89\%-18,53\%. Kandungan karbon organik total pada fraksi lanau lempungan berkisar antara 15,74 \%-53,33\%. Kandungan karbon organik total lebih tinggi pada fraksi lanau lempungan dibandingkan dengan fraksi pasir.

Distribusi kandungan karbon organik total lebih dipengaruhi oleh jauh dekatnya sumber masukan bahan organik, lebih tinggi di daerah muara sungai dan lebih rendah ke arah lepas pantai. 


\section{DAFTAR PUSTAKA}

Arisa, R. R. P., E. W. Kusharono dan W. Atmodjo. 2014. Sebaran Sedimen dan Kandungan Bahan Organik Pada Sedimen Dasar Perairan Pantai Slamaran Pekalongan. Jurnal Marine Research. 3(3): 342-350.

Deming, J. W and P. L. Yager. 1992. Natural Bacterial Assemblages in Deeo-Sea Sediment: Towards a Global View. In: Rowe G.T., Pariente V. (Eds), Deep-Sea Food Chains and the Global Carbon Cycle. Kluwer Academic Publisher, Dordrecht, 11-27.

Hutasoit, S. R., S. Y. Wulandari dan Muh. Yusuf. 2014. Distribusi Kandungan Karbon Organik Total (KOT) dan Fosfat di Perairan Sayung, Kabupaten Demak. Jurnal Oseanografi. 3(1): 74-80.

Meng, J., P. Yao, Z. Yu, T. S. Bianchi, B. Zhao, H. Pan and D. Li. 2014. Speciation, Bioavailability and Preservation of Phosphorus of the Changjiang Estuary and Adjacent East China Sea Inner Shelf. Estuarine, Coastal and Shelf Science., 144:27-38.

Nurfakih, A dan C. A. Suryono. 2013. Studi Kandungan Bahan Organik Sedimen Terhadap Kelimpahan Bilvalvia Di Perairan Semarang Bagian Timur, pp. 173-180.

Pangestu, H. dan H. Haki. 2013. Analisa Angkutan Sedimen Total Pada Sungai Dawas Kabupaten Musi Banyuasin. Jurnal Teknik Sipil dan Lingkungan. 1(1).

Poerbandono dan E. Djunarsjah. 2005. Survei Hidrografi. Refika Aditama, Bandung. $155 \mathrm{hlm}$.

Riniatsih, I. 2015. Distribusi Muatan Padatan Tersuspensi (MPT) di Padang Lamun di Perairan Teluk Awur dan Pantai Prawean Jepara. Jurnal Kelautan Tropis. 18(3): 121-126.

Sosrodarsono, S. dan K. Takeda. 2003. Hidrologi Untuk Pengairan. PT. Pradnya Pramita. Jakarta. 328 hlm.

Subandi. 2011. Deskriptif Kualitatif Sebagai Satu Metode Dalam Penelitian Pertunjukan. Institut Seni Indonesia Surakarta. Harmonia. 11(2).

Sugiyono. 2009. Meode Penelitian Kuantitatif Kualitatif dan R\&D. Alfabeta. Bandung,334 hlm.

Supriadi, I. H. 2001. Dinamika Estuaria Tropik. Oseana. XXVI(4): 1-11.

Wibisono, M. .2005. Pengantar Ilmu Kelautan. Penerbit Universitas Indonesia: Jakarta. $255 \mathrm{hlm}$. 